\title{
Climate and soil effect on oil palm (Elaeis guineensis Jacq.) yield
}

\author{
Aceves-Navarro, Lorenzo Armando ${ }^{1}$; Rivera-Hernández, Benigno ${ }^{2 *}$; Arrieta-Rivera, Agricola ${ }^{3}$; \\ Juárez-López, José Francisco $^{1}$; González-Mancillas, Rigoberto ${ }^{4}$; Villarreal-Fuentes, Juan Manuel ${ }^{5}$
}

${ }^{1}$ Colegio de Postgraduados-Campus Tabasco, Carretera Cárdenas-Huimanguillo km 3.5, G.P. 86500, Cárdenas, Tabasco, México.

${ }^{2}$ Universidad Popular de la Chontalpa, Carretera Cárdenas-Huimanguillo, km 2.0, R/a Pazo y Playa, Cárdenas, Tabasco.

${ }^{3}$ Instituto Tecnológico de la Zona Olmeca, Prolongación Ignacio Zaragoza S/N, Villa Ocuiltzapotlán, Centro, Tabasco, México.

4 Tecnológico Nacional de México/Instituto Tecnológico de la Guenca del Papaloapan(ITCP), Av. Tecnológico No. 21, CP. 68446, San Bartolo Tuxtepec, Oaxaca.

5 Facultad de Ciencias Agrícolas Campus IV, Universidad Autónoma de Chiapas, Entronque Carr. Costera y Estación Huehuetán, Huehuetán, Chiapas, México.

* Correspodence: benigno.rivera@upch.mx

Gitation: Aceves-Navarro, L. A., Rivera-Hernández, B., Arrieta-Rivera, A., Juárez-López, J. F., GonzálezMancillas, R., \& Villarreal-Fuentes, J. M. (2021). Climate and soil effect on oil palm (Elaeis guineensis Jacq.) yield. Agro Productividad. https://doi.org/ 10.32854/ agrop.v14i10.2005

Editor in Chief: Dr. Jorge Cadena Iñiguez

Received: February 14, 2021. Accepted: September 19, 2021. Published on-line: November 8, 2021

This work is licensed under a

Creative Commons Attribution-NonCommercial 4.0 International license.

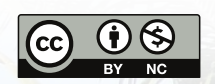

\section{ABSTRACT}

Objective: To determine potential and water-limited yields in oil palm producing areas in the State of Tabasco, México.

Design/Methodology/Approach: The ERIC III v. 3.2 database (IMTA, 2009) was used to select climatological stations with daily precipitation and maximum and minimum temperature records, going back to more than 20 years. The methodology proposed by the FAO and improved by Fischer et al. (2012) was used to estimate the potential yield. The equation reported by Ruiz-Álvarez et al. (2012) was used to estimate the annual water deficit from the climatic water balance.

Results: The average potential yield of oil palm with a high level of inputs varies from 35.8 to $40.6 \mathrm{tha}^{-1}$ of fresh fruit bunches. The average water-limited yield can vary from 15.6 to $23.5 \mathrm{t} \mathrm{ha}^{-1}$ in plantations of at least 8 years of age, under rainfed conditions. The reduction in the maximum average attainable yield was the result of 19.2-49.5\% soil moisture deficits.

Study limitations/Implications: In order to determine their impact on potential and water-limited yields, climate change horizons must be included in future studies; this would enable researchers to establish the future theoretical economic profitability of the crop.

Findings/Conclusions: The analysis between the yields indicates that -if the gap between the current yields and water-limited yields is closed-output and percentage would be 6.5-14.4 $\mathrm{t} \mathrm{ha}^{-1}$ and $72.8-129 \%$ higher than the potential yield.

Key words: yield gap, annual water deficit, water balance, potential yield. 


\section{INTRODUCTION}

In the State of Tabasco, 26.718 ha of oil palm are grown in the Sierra and Ríos subregions. The average yield is $15.4 \mathrm{tha}^{-1}$ (SIAP-SADER, 2021), almost $42 \%$ less than Guatemala's average yield. In tropical regions, such as Tabasco, precipitation is usually the main cause that limits the growth and yield of fresh fruit bunches (Corley and Tinker, 2008).

Oil palm yields are exponentially reduced as the annual water deficit increases. This has allowed other researchers to evaluate and forecast the annual production (Corley and Tinker 2008; Sparnaaij, 1960; Spanaaij et al., 1963; Ochs and Daniel, 1976). The French Institut de Recherche pour les Huiles et Oleagineus (IRHO) establishes a maximum attainable yield of $30 \mathrm{t} \mathrm{ha}^{-1}$ for fresh fruit bunches. The maximum attainable yield can face an approximately $10 \%$ reduction per $100 \mathrm{~mm}$ of annual water deficit (Corley and Tinker, 2008).

Water requirement becomes equal to the reference evapotranspiration value $\left(\mathrm{ET}_{0}\right)$; when plants consume water quantities equal to $\mathrm{ET}_{0}$, a maximum production of dry matter is expected to take place (Dufrene et al., 1992).

Annual water deficit takes place up to two years after the oil palm culture has been subject to water stress (Corley and Hong, 1981; Lubis et al., 1993). The main objective of this study was to determine the potential and the water-limited yields in the oil palm producing areas of the State of Tabasco. Additionally, we analyzed and compared the existing gaps between yields.

\section{MATERIALS AND METHODS}

Study Area. The study was carried out in the two oil palm producing subregions of the State of Tabasco. Seven climatological stations were selected: Teapa, Jalapa, Tacotalpa, and Macuspana (Sierra) and Balancán, Tenosique, and Emiliano Zapata (Ríos) (INEGI, 2015).

Climatological Data. Once the seven climatological stations were selected, the ERIC III v. 3.2 (IMTA, 2009) data base was used to obtain their daily data, monthly precipitation, and monthly maximum and minimum temperatures. The daily data records ranged from 20 to 50 years, depending on the selected locations. Only full years were selected for each series. Most of the stations do not record the climate variables, which are necessary to estimate potential and water-limited oil palm yields; instead, temperatures were used to carry out this task.

The monthly average global solar radiation $(R g)$ data were estimated using the Hargreaves-Samani equation proposed by the FAO when there is no data for this variable (Allen et al., 2006). Equation (1):

$$
R g=0.16 * \sqrt{T_{\max }-T_{\min }} * R_{a}
$$

Where $R g=$ global solar radiation $\left(\mathrm{MJ} \mathrm{m} \mathrm{m}^{-2} \mathrm{~d}^{-1}\right)$ and $R_{a}=$ extraterrestrial radiation $(\mathrm{MJ}$ $\left.\mathrm{m}^{-2} \mathrm{~d}^{-1}\right)$. Ra was estimated using the latitude data of the climatological station and the date (Allen et al., 2006). 
The reference evapotranspiration $\left(\mathrm{ET}_{0}\right)$ values are essential to carry out a water balance and to determine the annual water deficit. The Hargreaves-Samani (1985) equation was used to carry out the estimate. Equation (2):

$$
E T_{0}=0.0023 *\left[\left(T_{\max }-T_{\min }\right)^{0.50}\right] *\left(17.8-T_{\text {med }}\right) *\left(\frac{R_{a}}{2.45}\right)
$$

Where $E T_{0}=$ reference evapotranspiration $\left(\mathrm{mm} \mathrm{d}^{-1}\right), T_{m e d}=$ average daily temperature $\left({ }^{\circ} \mathrm{C}\right), T_{\max }=$ daily maximum temperature $\left({ }^{\circ} \mathrm{C}\right), T_{\min }=$ daily minimum temperature $\left({ }^{\circ} \mathrm{C}\right)$ and $R_{a}=$ extraterrestrial radiation $\left(\mathrm{MJ} \mathrm{m} \mathrm{m}^{-2} \mathrm{~d}^{-1}\right)$.

Yield Type. Scientific literature mentions at least three types of yield: actual yield, water-limited attainable yield, and potential yield. The average or actual yield is the output that producers obtain, and it varies in time. It is limited by nutrients and water. Weeds, pests, blights, and plantation management contribute to its reduction. The attainable yield is only limited by water deficit in the soil and is equivalent to a waterlimited potential yield, in rainfed condition areas. Potential yield has no limitations, except those imposed by the $\mathrm{CO}_{2}$ concentration in the air, global solar radiation, temperature, and crop characteristics (physiology, phenology, canopy structure, etc.). Van Ittersum and Rabbinge (1997), Fischer et al. (2012), Fischer (2015), and Woittiez et al. (2017) discussed these types of yields in detail.

Actual Yield (2019). The data provided by SIAP-SADER (2021) for the 2010-2019 oil palm yields in the oil palm producing municipalities of the State of Tabasco are shown in Table 1.

Calculation of the reduction of water-limited attainable yield. The reduction of the water-limited attainable yield of oil palm is calculated on the basis of the relation between the annual water deficit (DHA) and the oil palm yield. Several authors have reported this relation: Spanaaij (1960), Sparnaaij et al. (1963), Ochs and Daniel (1976),

Table 1. 10-year Evolution of Yields in the Oil Palm Producing Municipalities of Tabasco (2010-2019).

\begin{tabular}{|c|c|c|c|c|c|c|c|c|c|c|c|}
\hline \multirow{2}{*}{ Municipality } & \multicolumn{10}{|c|}{ Year } & \multirow{2}{*}{ Average } \\
\hline & 2010 & 2011 & 2012 & 2013 & 2014 & 2015 & 2016 & 2017 & 2018 & 2019 & \\
\hline Balancán & 4.0 & 7.0 & 15.0 & 17.3 & 22.8 & 12.8 & 12.6 & 13.0 & 14.2 & 14.1 & 13.3 \\
\hline Centro & 20.7 & 26.0 & 25.4 & 21.5 & 18.0 & 15.8 & 17.6 & 16.9 & 17.8 & 17.7 & 19.7 \\
\hline Emiliano Zapata & 4.0 & 8.0 & 8.9 & 16.0 & 8.0 & 12.4 & 14.7 & 14.0 & 14.6 & 16.6 & 11.7 \\
\hline Jalapa & 26.0 & 28.7 & 29.3 & 27.8 & 23.1 & 18.4 & 23.7 & 20.0 & 20.5 & 20.7 & 23.8 \\
\hline Macuspana & 22.0 & 24.0 & 25.2 & 23.2 & 22.1 & 13.0 & 21.0 & 14.0 & 16.3 & 16.4 & 19.7 \\
\hline Tacotalpa & 19.0 & 20.9 & 24.4 & 17.8 & 15.6 & 15.4 & 17.2 & 18.8 & 19.3 & 19.4 & 18.8 \\
\hline Teapa & 25.5 & 34.0 & 24.5 & 31.7 & 12.3 & 16.2 & 18.0 & 18.5 & 18.5 & 18.8 & 21.8 \\
\hline Tenosique & 5.5 & 7.0 & 8.9 & 6.5 & 9.6 & 10.5 & 10.0 & 9.4 & 10.1 & 10.4 & 8.8 \\
\hline State average & 9.8 & 12.0 & 16.0 & 16.4 & 17.2 & 13.5 & 14.8 & 14.0 & 14.8 & 15.5 & 14.4 \\
\hline
\end{tabular}


Corley and Hong (1981), and Corley and Tinker (2008). This study takes into account the relation reported by Corley and Tinker (2008), which relates DHA with relative yield. The relation has an exponential behavior. Equation (3):

$$
Y=100 * e^{(-0.00169 * X)}
$$

Where $X=$ DHA value and $Y=$ percentage decline regarding a $100 \%$ maximum potential attainable yield. The relative yield values reported by Corley and Tinker (2008) were obtained from the yield data of the world's main oil palm producing countries. Subsequently, that data — resulting from applying equation (3) - was expressed as a percentage reduction of the maximum yield $(100 \%)$. The aim was to visualize the percentage reduction of the attainable yield with regard to a maximum yield established according to various DHA values. The resulting equation was the following:

$$
Y=0.1602 * X-0.00009 * X^{2}\left(\mathrm{R}^{2}=0.999\right)
$$

Where $Y=$ relative reduction of attainable yield (\%) and $X=$ annual water deficit $(\mathrm{mm})$.

The IRHO reports that, for every 100 millimeters of DHA, an average $2.88 \mathrm{t} \mathrm{ha}^{-1}$ yield reduction takes place in palms that were at least 8 years old and under rainfed conditions.

Potential Yield Calculation. To calculate potential oil palm yield we need to find out the daily and monthly average values of global solar radiation, average temperature, and diurnal temperature, as well as leaf area and crop harvest indexes. The average and diurnal temperatures are obtained based on maximum and minimum temperatures. Diurnal temperature is calculated using the equation (5) proposed by Aceves Navarro et al. (2017). Oil palm leaf area and crop harvest indexes for a high supply level is 6.0 and 0.60 , respectively (Fischer et al., 2012). Equation (5):

$$
T_{\text {diu }}=T_{\max }+0.25 *\left(T_{\max }-T_{\min }\right)
$$

Where $T_{d i u}=$ diurnal temperature; $T_{\max }=$ maximum temperature; and $T_{\min }=$ minimum temperature.

The potential yield calculation procedure is based on the methodology proposed by the FAO and improved by Fischer et al. (2012). Rivera-Hernández et al. (2012) described the said calculation in detail.

Annual Water Deficit (DHA) Estimate. Water deficit can be estimated for any period based on a climatic water balance (Ruiz-Álvarez et al., 2012). A one-month period was selected for this study. Equation (6):

$$
B H_{i}=S W_{i}+P P t_{i}-E T_{0_{i}}
$$


Where $B H_{i}=$ climatic water balance of the $i$ (current month) (mm); $S W_{i}=$ theoretically useful soil moisture reserve, at the beginning of the $i$ period, at a one-meter depth $(\mathrm{mm})$; $P P t_{i}=$ total precipitation of $\mathrm{i}$ (current month) $(\mathrm{mm}) ; E T_{0_{i}}=$ reference evapotranspiration of $i$ (current month) (mm); and $i=$ selected period (month).

Negative values for the monthly water balance $(B H)$ result in a deficit. An annual water deficit (DHA) consists of the yearly sum of the monthly $B H$ negative values. We calculated the water-limited yield and its relative reduction regarding the maximum attainable yield, taking into account the annual water deficit of every recorded year and using equations (3) and (4).

In the oil palm producing regions of the world, the useful moisture reserve at a onemeter depth in the soil, varies from $83 \mathrm{~mm}$ to $167 \mathrm{~mm}$ (Corley and Tinker, 2008). To guarantee a 100-mm minimum supply of useful moisture, this study was carried out at a depth of one meter, following the findings of López et al. (2007) for the soil textures predominant in the Ríos and Sierra subregions. The $\mathrm{BH}$ was carried out during November in order to guarantee that the soil had reached its maximum water retention capacity, as a result of the abundant precipitations of October.

Expected Return Periods. A probability distribution function was fitted to the data resulting from the annual water deficit and the relative annual yield reduction at each selected climatological station, and the exceedance probability and its matching return periods were calculated.

\section{RESULTS AND DISCUSSION \\ Return Periods}

The results show that the annual water deficit and the relative yield reduction at the Jalapa, Balancán, Emiliano Zapata, and Tenosique climatological stations fitted a regular probability distribution function. On the contrary, the Transformation of the Normal (Fourth Root) was a better fit for the Macuspana, Tacotalpa, and Teapa climatological stations. The exceedance probability and return period for the annual water deficit and the relative reduction of the relative yield were calculated based on the probability distribution functions, enabling the definition of annual water deficit values and reduction with a oneyear return period (i.e., values that will be recorded every year while a moisture deficit remains). Table 2 shows these values for the chosen stations.

Table 2 shows that there will be yearly reductions in the average attainable yields, as a result of the deficient rainwater supply during the yearly dry periods. This work proves that every year there is a reduction of the water-limited yields with regard to the maxim attainable yields $\left(30 \mathrm{tha}^{-1}\right)$ reported by the IRHO.

\section{Actual Yield}

From 2010 to 2019, the average yield in the State of Tabasco was $14.4 \mathrm{t} \mathrm{ha}^{-1}$ (Table 1). The average yields in the Sierra subregion were higher than the yields reported for the Ríos subregion. There were time-dependent variable yields in both subregions. On the 
Table 2. Annual Water Deficit (AWD) and Reduction of the Attainable Yield (RAY) Values with a One-Year Return Period.

\begin{tabular}{l|c|c}
\hline \multirow{2}{*}{ Municipality } & \multicolumn{2}{|c}{ Securities with a return period of one year } \\
\cline { 2 - 3 } & AWD $(\mathbf{m m})$ & RAY $(\%)$ \\
\hline Jalapa & 364.6 & 46.0 \\
\hline Macuspana & 221.5 & 31.2 \\
\hline Tacotalpa & 172.4 & 25.3 \\
\hline Teapa & 87.5 & 13.7 \\
\hline Balancán & 273.5 & 37.0 \\
\hline Emiliano Zapata & 324.5 & 42.2 \\
\hline Tenosique & 229.4 & 32.1 \\
\hline
\end{tabular}

one hand, this phenomenon was partly the result of the different plantation ages — since not all of them have reached their maximum production yet and therefore they follow the behavior described by Woittiez et al. (2017). On the other hand, this phenomenon is partly the result of the annual rainfall volume variations - which define the annual water deficit differences that have a differentiating impact on yields.

\section{Reduction of the Maximum Attainable Yield}

The climatic water balance showed that the average annual water deficit fluctuated between 152.3 and $410.6 \mathrm{~mm}$, in the oil palm producing municipalities of the State of Tabasco (Table 3). Table 3 also shows the average actual attainable yield in tons and its reduction percentage regarding their maximum attainable potential. The average waterlimited yield ranges from 15.2 to $23.5 \mathrm{t} \mathrm{ha}^{-1}$. It should be pointed out that average values (50\% probability) actually mean the recurrence of the said values with a 2-year return period.

Based on the results shown in Table 3, if auxiliary irrigation was used to close the gap between the maximum attainable yield and the actual water-limited yields, it could be possible to achieve a 5.8-14.8 $\mathrm{tha}^{-1}$ increase of oil per year - or a 1.5-3.7 ha $\mathrm{ha}^{-1}$ increase for

Table 3. Annual Water Deficit (AWD) and Actual Average Water-Limited Yield per Ton and Maximum Attainable Reduction Percentage.

\begin{tabular}{|c|c|c|c|}
\hline \multirow{2}{*}{ Municipality } & \multirow{2}{*}{$\operatorname{AWD}(\mathbf{m m})$} & \multicolumn{2}{|c|}{ Actual Average Water-Limited Yield } \\
\hline & & $\left(\mathbf{t h a}^{-1}\right)$ & Decrease (\%) \\
\hline Jalapa & 410.6 & 15.2 & 49.5 \\
\hline Macuspana & 300.4 & 18.4 & 36.9 \\
\hline Tacotalpa & 167.1 & 22.6 & 23.8 \\
\hline Teapa & 152.3 & 23.5 & 19.2 \\
\hline Balancán & 323.2 & 17.6 & 41.3 \\
\hline Emiliano Zapata & 330.2 & 17.5 & 41.8 \\
\hline Tenosique & 294.9 & 18.6 & 37.9 \\
\hline
\end{tabular}

(*) AWD: average annual water deficit. (**) Reduction with regard to a $30 \mathrm{t} \mathrm{ha}^{-1}$ yield according to IRHO (Corley and Tinker, 2008). 
its equivalent. Table 3 also shows that there will always be an average 150-410 mm annual water deficit, equivalent to 4.3-11.8 $\mathrm{ha}^{-1}$ yield reductions.

The analysis of historical weather data from the two oil palm producing subregions of the State of Tabasco proves that there is a moisture deficit every year; therefore, there will always be reductions to the maximum attainable yield, proportional to the annual water deficit value. According to the results of the area covered by the Teapa climatological station, the actual water-limited oil palm yields under rainfed conditions fluctuated between 14.0 and $30 \mathrm{tha}^{-1}$ (average value: $23.5 \mathrm{t} \mathrm{ha}^{-1}$ ).

Meanwhile, in the area covered by the Balancán municipality — which includes most of the oil palm producing areas of the State of Tabasco-, an average yield of $13.1 \mathrm{t} \mathrm{ha}^{-1}$ has been reported (similar to the national average) (SIAP-SADER, 2021). Clearly, plantation fertilization and weed, pest, and blight control must be improved in order to increase yields. The maximum attainable yield could be achieved through the use of auxiliary irrigation; this would reduce or eliminate water deficit in the oil palm producing areas; the yield could even exceed $40 \mathrm{tha}^{-1}$, in those areas which have been established as highly suitable as a result of their soil and climate conditions (Aceves et al., 2008). The municipality of Tacotalpa has the best weather conditions for the rainfed production of oil palms: 2 out of 10 years have no annual water deficit.

\section{Potential Yields}

The average potential yields for oil palms are very similar from one subregion to another (Table 4): they have a non-significative $300 \mathrm{~kg} \mathrm{ha}^{-1}$ difference. The low variation is the result of the high similarity of the space-time distribution of global radiation and diurnal temperature. These average yields must be set as a goal for high-tech oil palm plantations that have appropriate water supply.

\section{Yield Gap Analysis}

Table 5 shows the average yield for the various types of yield. The gap that exists between the average actual and water-limited yields can be observed when they are compared with the maximum attainable and potential yields (Table 5). Analyzing these gaps can help to explore ways to improve plantation productivity (van Ittersum and Rabinge, 1997).

Table 4. Average Potential Yields in the Oil Palm Producing Municipalities of the State of Tabasco.

\begin{tabular}{l|c}
\multicolumn{1}{c}{ Municipality } & Potential yield $\left(\mathbf{t ~ h a}^{-\mathbf{1}}\right)$ \\
\hline Jalapa & 40.6 \\
\hline Macuspana & 37.3 \\
\hline Tacotalpa & 36.4 \\
\hline Teapa & 35.8 \\
\hline Balancán & 38.2 \\
\hline Emiliano Zapata & 36.6 \\
\hline Tenosique & 36.9 \\
\hline
\end{tabular}


Table 5. Yield Types and their Average Variation per Tons of Fresh Fruit Bunches $(*)$.

\begin{tabular}{l|c}
\hline \multicolumn{1}{c|}{ Yield type } & Average yield $\left(\mathbf{t ~ h a}{ }^{-\mathbf{1}}\right)$ \\
\hline Current average & 9.8 a 17.2 \\
\hline Achievable maximum & 30.0 \\
\hline Limited by current water & 15.6 a 23.5 \\
\hline Potential & 35.8 a 40.6 \\
\hline (*) Resulting values under historic environmental conditions.
\end{tabular}

Additionally, Table 5 shows that — given the prevailing weather, soil, and handling conditions in the State of Tabasco - actual yields only represent 32.7-57.3\% of the maximum attainable yield. Consequently, if the gap is closed through auxiliary irrigation and improved handling practices, a 12.8-20.2 $\mathrm{t} \mathrm{ha}^{-1}$ increase of actual yields can be expected, just as Donough et al. (2009); Cavalche (2013), and van Ittersum and Rabinge (1997) reported. For example, according to De Taffin and Daniel (1976), auxiliary irrigation increased yields from 12 to $31 \mathrm{t} \mathrm{ha}^{-1}$ over a 3-year period. Meanwhile, Cavalche (2013) reports that auxiliary irrigation increased oil palm yield in Ecuador by $21.3 \%$ during the first year and that investing in irrigation had an over 2.7 cost-benefit ratio. For their part, Van Kraalingen et al. (1989) reported that 6-12-year-old plantations can produce up to $34.1 \mathrm{t} \mathrm{ha}^{-1}$ of fresh fruit bunches; meanwhile, Corley and Tinker (2008) report that the maximum growth rates for mature palm oil plantations with 6-7 leaf area indexes in theory can produce up to $50 \mathrm{t} \mathrm{ha}^{-1}$.

Nevertheless, measures taken to close the oil palm yield gaps require a long time, as a consequence of the time gap between the moment in which the stressor takes place and the moment when it impacts the yields. This time gap can last up to 40 months: the gap between the flower's initiation and the fruit's ripening (Donough et al., 2009).

\section{CONGLUSIONS}

The maximum attainable yields will always be reduced - in proportion to the value of the annual water deficit - in the two-oil palm producing subregions. The actual average water-limited yield ranges from 15.2 to $23.5 \mathrm{t} \mathrm{ha}^{-1}$. The average potential yields for oil palms per subregion are very similar $\left(300 \mathrm{~kg} \mathrm{ha}^{-1}\right.$ difference). Actual yields represent only $32.7-57.3 \%$ of the maximum attainable yield.

\section{REFERENCES}

Aceves, N.L. A., Juárez, L.J. F., Palma, L.D.J., López, L.R., Rivera, H.B., Rincón, R.J.A., Morales, C.R. (2008). Estudio para determinar zonas de alta potencialidad del cultivo de palma de aceite (Elaeis guineensis Jacq) en el estado de Tabasco. Gobierno del estado de Tabasco-SAGARPA-Colegio de Postgraduados-INIFAP. 34 pp.

Aceves-Navarro, L. A., Rivera-Hernández, B., Juárez-López, J. F., Arrieta-Rivera, A. (2017). Nuevo procedimiento para estimar rendimientos potenciales de cultivos a partir de la temperatura diurna. En: Martínez Herrera J, Ramírez Guillermo MA y Cámara-Córdova J. (Eds). Seguridad Alimentaria: Aportaciones Científicas y Agrotecnológicas. UJAT-INIFAP, 06 de nov. 2017. Villahermosa, Tab. México. pp. 93-99. 
Allen, R.G., Pereira, L.S., Raes, D., Smith, M. (2006). Evapotranspiración del cultivo-Guías para la determinación de los requerimientos de agua de los cultivos. FAO Irrigation and Drainage Paper, No. 56. FAO, Rome. 322 p.

Cavalche, M.V.G. (2013). Influencia del riego en la rentabilidad del cultivo de la palma aceitera (Elaeis guineensis Jacq.) en la zona de la Concordia-Santo Domingo de Tsáchilas, Ecuador. Disponible en: https//www. researchgate.net/publications/301778904. Fecha de consulta: 02 de marzo de 2021.

Corley, R.H.V., Tinker, P.B. (2008). The Oil Palm. Fourth Edition. Blackwell, Science Ltd. Oxford, UK. 562 p.

Corley, R.H.V., Hong, T.K. (1981). Irrigation of oil palms in Malaysia. In: (E. Pushparajah; P.S. Cnew, (Eds.)). International Conference on the Oil Palm in Aqriculture in the Eighties. Proceedings. PORIM, Kuala Lumpur. vol.2, p.343-356.

Daniel, C., de Taffin, G. (1974). Conduite des jeunes plantations de palmier á huile en zones séches au Dahomey. Oléagineux, 29, (5). 227-232.

De Taffin, G., Daniel, C. (1976). First results from a trial of slow irrigation on oil palm. Oléagineux. 31, (10).

Donough, C.R., Witt, G., Fairhurst, T.H. (2009). Yield intensification in oil palm through best management practice. Better Crops, 93(1):12-14.

Dufrene, E., Dubos, B., Rey, H., Quencez, P., Saugier, B. (1992). Changes in evapotranspiration from an oil palm stand (Elaeis guineensis Jacq.) exposed to seasonal water deficits. Acta Ecologica, 13: 299-314.

Fitotecnia-Chapingo. Producción de oleaginosas. (2018). Disponible en: https://fitotecnia.chapingo.mx/wpcontent/uploads/2018/08/61_6_Producció_de_oleaginoas.pdf.

Fischer, G., Nachtergaele, F.O., Prieler, S., Teixeira, G., van Velthuizen, H., Verelst, L., \& Wiberg, D. (2012). Global Agro-Ecological Zones (GAEZ v3.0): Model Documentation. IIASA/FAO, Luxenburg, Austria and FAO Rome, Italy. 179 p.

Fischer, R.A. (2015). Definitions and determination of crop yield gaps, and of rates of change. Field Crops Res, 182; 9-18. Doi: 10.1016/j.fcr.2014.12.006

Hargreaves, G.H., Samani, Z.A. (1985). Reference crop evapotranspiration from temperature. Applied Eng. in Agric, 1(2): 96-99. Doi: 10.13031/2013.26773

INEGI, (Instituto Nacional de Estadística y Geografía). (2015). Síntesis Geográfica del Estado de Tabasco. (En línea). Disponible en: www3.inegi.org.mx/sistemas/mexicocifras

IMTA, (Instituto Mexicano de Tecnología del Agua). (2009). ERIC III: Extractor Rápido de Información Climatológica v.2. CD, p. 28.

López, G.A.D.R., Palma, G.B., Hernández, R.M.A., Ojeda, M.M.E., Angeles, P.A., Ruiz, N.J.A., Garcia, M.M.J. (2007). Caracterización fisicoquímica de los suelos predominantes en el estado de Tabasco. Conciencia Tecnológica, 7(34): 45-46.

Lubis, A.U., Endang, S., Kabul, P. (1993). Effect of long dry season on oil palm yield at some plantations in Indonesia. In: International Palm Oil Congress, Proceedings. PORIM, Kuala Lumpur. p.253-262.

Ochs, R., \& Daniel, C. (1976). Research on techniques adapted to dry regions. In: Developments in Crop Science 1. Oil Palm Research. Edited by Corley, R. H. V., Hardon, J. J. and B. J. Wood. Elsevier Pub. Co. Amsterdam, The Netherlands. pags. 183-213.

Rivera-Hernández, B., Aceves-Navarro, L. A., Juárez-López, J. F., Palma-López, D.J., González-Mancillas, R., González-Jiménez, V. (2012). Zonificación agroecológica y estimación del rendimiento potencial del cultivo de yuca (Manihot esculenta Crantz) en el estado de Tabasco. Avances de Investigación Agropecuaria, 16(1). 29-47.

Ruiz-Álvarez, O., Arteaga-Ramírez, R., Vázquez-Peña, M. A., Ontiveros-Capurata, R. E., \& López-López, R. (2012). Balance hídrico y clasificación climática del estado de Tabasco, México. Universidad y Ciencia, 28(1).1-14.

SIAP-SADER, (Servicio de Información Agroalimentaria y Pesquera-Secretaría de Agricultura y Desarrollo Rural). (2021). Agricultura. Disponible en http://www.nube.siap.gob.mx/cierreagricola

Sparnaaij, L.D. (1960). The analysis of bunch production in the oil palm. West. Afr. Inst. Oil Palm Res, 3. 109180.

Sparnaaij, L.D., Rees, A.R., Chapas, L.D. (1963). Annual yield variation in the oil palm. West. Afr. Inst. Oil Palm Res, 4: 111-125.

van Ittersum, M. K., Rabbinge, R. (1997). Concepts in production ecology for analysis and cuantification of Agricultural input-ouput combinations. Field crops Res, 52(3), 197-208. Doi: 10.1016/S03784290(97)00037-3

van Kraalingen, D.G.W., Breure, G.J., Spitters, G.J.T. (1989). Simulation of oil palm growth and yield. Agric. For. Meteorol, 46(3): 227-244. Doi: 10.1016/0168-1923(89)90066-X

Woittiez, L.S., van Wiljk, M.T., Slingerland, M.,van Noordwijk, M.E. (2017). Yield gap in oil palm. A quantitative review of contributing factors. Europ. J. Agronomy, 83: 57- 77. Doi: 10.1016/j.eja.2016.11.002 